\title{
Palliative care in Latvia: Availability and the role of the family doctor
}

\author{
Baiba Strautmane, Daiga Behmane $^{1}$, and Iveta Ludviga ${ }^{2}$ \\ ${ }^{1}$ Rīga Stradinš̌ University, Faculty of Public Health and Social Welfare, Institute of Public Health, \\ Riga, Latvia \\ ${ }^{2}$ RISEBA University of Applied Sciences, Postgraduate Study Programme director, Riga, Latvia
}

\begin{abstract}
In line with rapid population aging, palliative care is becoming increasingly important. The purpose of the study is to evaluate the satisfaction with palliative care and its availability in Latvia, as well as identify factors which have a major impact on overall satisfaction with care. The paper describes the situation in Latvia by evaluating the satisfaction with the palliative care and the accessibility to it. The study relies on a quantitative methodology and primary data were obtained using structured online survey conducted during the 30-day period - in March and April 2018. In total 240 questionnaires were collected from which $131(n=131)$ were qualified for further analysis. The survey results indicated that the population of Latvia has insufficient information about the palliative care leading to low availability. The regression analysis showed that overall low assessment of the palliative care is influenced by two factors: 1) low satisfaction with the services provided by the primary care physicians (family doctors), 2) satisfaction with the received palliative care services and the availability of the services. The study indicated that there is no unified and comprehensive palliative care strategy and system in Latvia, however, some state-provided care is available for a limited number of patients. The results highlight the necessary improvements in palliative care in Latvia and may serve as a basis for health and social policymakers for the development of a unified and comprehensive population end-of-life or palliative care strategy.
\end{abstract}

Key words: palliative care in Latvia, barriers to palliative care, patient satisfaction, health care system, end-of-life care strategy.

\section{Introduction}

In the context of the rapid ageing and structural changes of population, Latvia must count on an increase in chronic non-communicable diseases. The aim of hospice care is to ensure the best possible quality of life not only for oncology patients and their family members, but also for all patients with chronic and non-communicable diseases up to the end of their life time. Palliative care is the prevention and relief of any kind - physical, psychological, social, or spiritual suffering.

Globally, it is estimated that palliative care is needed in $40-60 \%$ of all deaths [1]. Palliative care is required for a wide range of diseases. The majority of adults in need of palliative care have chronic diseases such as cardiovascular diseases $(38.5 \%)$, cancer (34\%), chronic respiratory diseases (10.3\%), AIDS (5.7\%) and diabetes (4.6\%). Many other conditions may require palliative care, including kidney failure, chronic liver disease, multiple sclerosis, Parkinson's disease, rheumatoid arthritis, neurological disease, dementia, congenital anomalies, and drug-resistant tuberculosis [1]. 
According to OECD 2017 data people in OECD countries are living longer, but the burden of mental illness and chronic disease is emerging. Life expectancy at birth in 2015 was 80.6 years, on average, across OECD countries, in Latvia it was lower, reaching only 74.6 years. The main causes of mortality in Latvia encounter circulatory system diseases (more than $1 / 2$ of all deaths) followed by cancer ( $\sim 1 / 4$ of all deaths), respiratory diseases and others. Longer life expectancy and declining fertility rates mean that older people make up an ever-increasing proportion of the populations of OECD countries. On average across OECD countries, the share of the population aged over 65 years increased from less than $9 \%$ in 1960 to $17 \%$ in 2015 and is expected to continue to increase, reaching $28 \%$ in 2050 . In Latvia accordingly, the share of the population aged over 65 in 2015 and 2050 is respectively expected to increase from $20 \%$ to $28 \%$, but population aged over $80 \%$ is expected to increase from $5 \%$ to $9 \%$ [2]. The above mentioned underlines the importance of considering issues related to the quality and availability of palliative care.

The aim of the study is to evaluate the satisfaction of patients and their family members with palliative care and its availability in Latvia, as well as identify factors which have a major impact on overall satisfaction with care. Two broad research questions are investigated: (1) which factors contribute to satisfaction of palliative care in Latvia and what the role of the family doctor is, and (2) what are the limitations to the availability of palliative care in Latvia.

The article is structured as follows. First, the essence and models of palliative care are discussed, followed by an empirical investigation in Latvia about factors affecting the satisfaction with palliative care and its availability. Further research findings are discussed, and conclusions presented.

\section{Palliative care}

Palliative care is explicitly recognised under the human right to health and becomes increasingly important with an aging population [3]. It should be provided through personcentred and integrated health services that pay special attention to the specific needs and preferences of individuals [1].

Pain is one of the most frequent and serious symptoms experienced by patients in need of palliative care. Opiate analgesics are essential for treating the pain associated with many advanced progressive conditions. For example, $80 \%$ of patients with AIDS or cancer, and $67 \%$ of patients with cardiovascular disease or chronic obstructive pulmonary disease experience moderate to severe pain at the end of their lives [1].

Other physical symptoms palliative care patients experience are anxiety, appetite loss, breathlessness, constipation, delirium, depression, diarrhoea, fatigue, nausea, pain and respiratory tract secretions, insomnia, etc. The most frequent and burdensome symptoms in patients with chronic, complex, life-limiting health problems tend to be the same across diseases [4].

Psychosocial support is another part of palliative care. Patients with life-threatening or terminal illness and their caregivers experience considerable stress, and health professionals need to be adequately trained or prepared to manage their stress. The health system and health facilities may need certain simple features to facilitate other end-of-life needs of a patient, such as spiritual needs, family support, legal support and a motivating physical environment [4].

Palliative care is not intended to hasten or postpone death but applies ethical principles, shared decision making and advanced care planning to identify patients' priorities and goals for their care at the end of life [4]. 


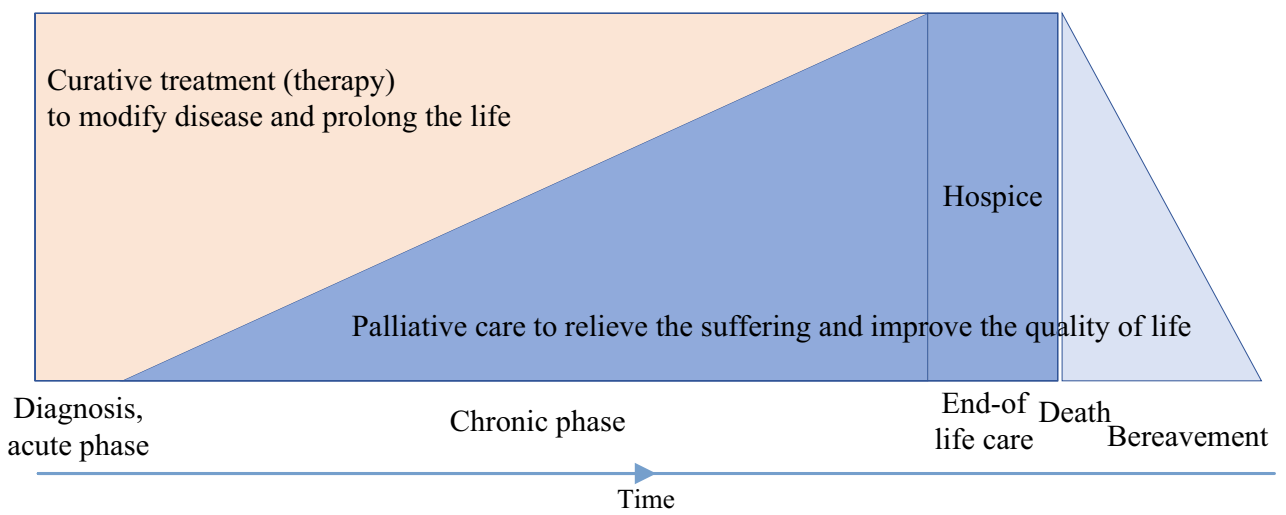

Fig. 1. Integrated palliative care. Source: adapted from WHO webpage http://www.who.int/ mediacentre/infographic/en/.

Palliative care means planning, coordination and information sharing that includes identifying support and resources available, development and implementation of a care plan based on patient's needs, facilitating the availability and access to medication (especially opiates). Palliative care also identifies the psychosocial/spiritual needs of professionals providing care [4].

Palliative care also includes education and informing the patients and their families about the palliative care and progress of the disease, therefore, communication is a critical issue. Palliative care specialists have to communicate with the patient, family, and caregivers about the disease, prognosis, treatment, symptoms and their management. Other issues are related to care in the last days/weeks of life, identification and setting priorities with patient and family/caregivers and to providing information and guidance to patients and caregivers.

Studies suggest that in developed world palliative care more often is available already during the early stage or chronic phase of the disease (Fig. 1) in conjunction with other therapies that are intended to prolong life, such as chemotherapy or radiation therapy, and includes those investigations needed to better understand and manage distressing clinical complications [5].

Hospice like palliative care provides also comprehensive comfort care as well as support for the family, but, in hospice, attempts to cure the person's illness are exhausted. The hospice usually is provided for a person with a terminal illness whose doctor believes he or she has 6 months or less to live if the illness runs its natural course [6]. Hospice is an approach to care; it is not tied to a specific place. It can be offered in two types of settings - at home or in a facility such as a nursing home, hospital, or even in a separate hospice centre.

The general palliative care is usually provided by physicians and other healthcare professionals from all disciplines (such as family medicine, cardiology, and oncology). The practice of palliative care is an interdisciplinary area, covering doctors, nurses, social workers, chaplains, and others, is being actively taken over in the world [7]. Caregivers need regularly to help patients and their family members to understand changes in the patient's health as they relate to current and future care and treatment goals [8]. In addition, specialist palliative care (specialised or specialty palliative care) has grown substantially [9]. Specialist palliative care is provided by a specially trained team of doctors, nurse practitioners, nurses, social workers, and other health care professionals, who work together with a patient's primary care team to provide an extra layer of support for people with serious illness [10]. 
The World Health Assembly Resolution 2014 on Palliative Care [11] called for all member countries to incorporate palliative care provision into their health care systems to ensure access to palliative care for all patients in need. Need for systemic approach was acknowledged by researchers as having a huge impact on the quality of care and the effectiveness of the entire healthcare system [12].

But still there are identified several barriers to palliative care that include lack of awareness among policy-makers, health professionals and the public about what palliative care is, and the benefits it can offer to patients and health systems, cultural and social barriers $[1,5,10]$. There are misconceptions about palliative care, such as that it is only for patients with cancer, or for the last weeks of life and misconceptions that improving access to opiate analgesia will lead to increased substance abuse [1].

Other identified barriers to access the palliative care are lack of information and knowledge about palliative care in general and about particular care availability, service or specialist unavailability close to patient's place of living $[5,10]$, as well the waiting time to receive the care service and financial implications if family have to pay extra to receive palliative care services.

Palliative care requires financial investments, but, on the other side, offers considerable savings $[1,5]$ in other health care sectors, such as emergency medical care. Advanced health care settings have referred to this fact as an incentive to expand immediate palliative care, as this leads to economy in the growing health care budgets.

\section{Method}

This study relies on a quantitative methodology. Literature analysis on palliative care models and their organization elsewhere in the world was used, as well analysis of Latvian social and healthcare legislation and planning documents helped to design the survey questions. To obtain data about the palliative care availability and to analyse the impact of palliative care availability and system's components on a patient and their family member satisfaction with the overall palliative care received in Latvia, the primary data were obtained using structured online survey. The logic of the survey design is explained below.

\subsection{Variables}

Dependent variable: In line with the aim of the research overall satisfaction with palliative care in Latvia was designed as the dependent variable and measured with a single item statement where measured using 7-point Likert scale where 1 was assigned to "care was not received' and 7 to 'high-quality care was received'.

Independent variables: The independent variables of the survey were chosen based on general palliative patient needs and services suggested by studies to meet these needs general practitioners provided care (primary care), palliative care specialist consultations (secondary care), access to assistive technologies, pain relief medication, pain and symptom management, pain relief (algology), care in hospitals, care at home, psychological support and spiritual support. To understand the reasons behind the patient and their family satisfaction or dissatisfaction or barriers to access of palliative care services like service unavailability close to living place, lack of information, lack of financing and long waiting time to receive particular care where also taken into account. Thus, disease symptom strengths, the strength of need for care, restrictions to receive the care and finally satisfaction with the provided care were developed as independent variables.

Since in Latvia the main patient contact point in healthcare and also in palliative care is a general practitioner or family doctor, patients and their family members were asked to 
evaluate separately the service and care provided at primary health care level particularly from palliative care perspective.

Control variables: several factors which may have an impact on overall satisfaction with care such as disease, patient's place of residence and living conditions (whether the patient lives alone, with relatives or in care institution) as well as age and gender of the patient and that of the respondent. These factors were included as control variables.

\subsection{Data}

The survey was executed to obtain data from all statistical regions of Latvia to get an overview of overall palliative service availability across country. The survey included only respondents who had experience with severe illness and non-treatable patients in age above 18 (to exclude paediatric patients) during the last 24 months. The online survey was conducted during the 30-day period - in March and April 2018. In total 240 questionnaires were collected from which 109 were excluded either not having a relationship with severely ill patients or not having complete information on patient's needs and care received. The qualified respondents $(n=131)$ were both patients and their relatives, representing patients from all age groups ( $41 \%$ were 75 years and older), $64 \%$ were female, and represented all Latvia's statistical regions (53\% patients were from Riga region). The most represented diseases were cancer (48\%), cardiovascular diseases (15\%), dementia and Alzheimer's disease (12\%), cerebrovascular (11\%) and musculoskeletal diseases (11\%), the remaining $4 \%$ indicated other diseases. $75 \%$ of the sample patients were living together with relatives, $17 \%$ were living alone and $8 \%$ in care institutions.

Since data were gathered using a questionnaire and thus rely on self-reported measures, it may be subject of common method bias (CMB). Hartman one-factor test was used to address common method bias [13] and Factor 1 accounted for $41.2 \%$ of the variance indicating that CBM is unlikely to affect the data. All scales showed acceptable to good internal consistency reliability - Cronbach's Alfa coefficients ranged between 0.76 to 0.91 what is above 0.7 [14]. Multicollinearity test showed that variance inflation factor (VIF) range between 1.27 and 1.85 , thus it is below 10, with an average being 1.63; and Tolerance from 0.54 to 0.75 what is well above 0.2 , thus showing no multicollinearity [15].

\section{Results and discussion}

In overall only $45.7 \%$ of respondents can be accounted as satisfied with the palliative care services while 54,3\% remain unsatisfied. Average evaluation of the overall satisfaction with palliative care was 3.51 in 7-point Likert scale with standard deviation 1.55, which shows low satisfaction rate with palliative care in Latvia. The detailed split of overall satisfaction is shown in Fig. 2.

To test the factor impact on overall satisfaction hierarchical regression analysis was used since it allows specifying a fixed order of entry for variables in order to test the effects of certain predictors independent of the influence of others (control variables). Table 1 summarises the results of the regressions: the estimated regression coefficients with their standard errors below them in are presented and the final six rows contain summary statistics. Model 1 to 5 present the effect of control variables and Model 6 and Model 7 present the effect of independent variable on the dependent variable (overall satisfaction with palliative care). Further the logic of the hierarchy is explained. Since variables are measured in different units of measurements, standardised coefficients are used for interpretation. 


\section{Overall satisfaction with palliative care in Latvia $(\mathrm{n}=131)$}

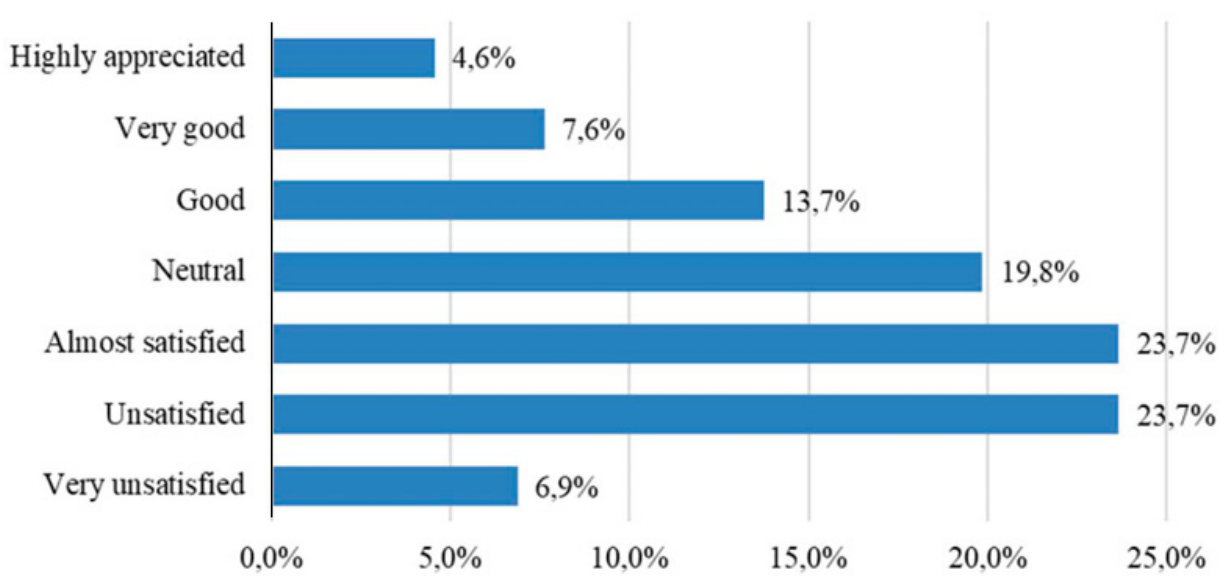

Fig. 2. Overall satisfaction with palliative care in Latvia (2018).

In the first step control variables (diagnosed diseases) were inserted (see Model 1). Disease dummies where created with 'other disease' as a baseline. All diseased have negative betas, as it might be expected still the model is not significant $\left(\bar{R}^{2}=0.04\right)$.

In the second model, patient's place of residence was entered using 'Riga and district' as a baseline. Model 2 is not statistically significant $\left(\bar{R}^{2}=0.04\right)$ showing that patients ' place of residence has no impact on the dependent variable. Patient's living conditions using 'living alone' as a baseline (Model 3) added no explanatory power since model is not significant $\left(\bar{R}^{2}=0.04\right)$. Patient's age and gender were entered in the fourth step (see Model 4). The model still remains not significant predictor $\left(\bar{R}^{2}=0.046\right)$. Model 5 adds respondent's age and gender, still no predictive power $\left(\bar{R}^{2}=0.07\right)$.

The results in Table 1 show that Models 1 to 5 are not statistically significant, thus, the type of the disease, place of residence and living condition, gender and age does not affect significantly the overall satisfaction with the care system. Therefore, the results can be equally related to all regions of Latvia, all diseases and all patients.

Further steps of hierarchical regression (Model 6 and Model 7) assess the impact of palliative care system's parameters and family doctor variable on the overall satisfaction of palliative care above the effect of control variables.

Model 6 shows the impact of the system's components excluding family doctor and shows statistically significant impact $\left(\bar{R}^{2}=0.332 ; p=0.000\right)$. Model adds $25 \%$ explanatory power and is statistically significant $\left(\Delta R^{2}=0.25^{* * *}\right)$. Moreover, satisfaction with the care provided by palliative care specialists appears to be the only factor with statistically significant impact ( $b=0.71^{* * *}$ and standardised coefficient $\beta=0.37^{* * *}$ ).

Figure 3 presents a detailed analysis of the variable 'satisfaction with the care provided by palliative care specialists. Figure 3 indicates that the most satisfied are people who received spiritual support and above average satisfied are people who could receive professional pain and other symptom management, pain medication, palliative specialist consultations, as well if palliative care is available at home or day centres. Thus, evidence in Latvia shows that more appropriate attention to the incurably ill patients should be paid by psychologists and professionals in hospitals, as well as the quality of assistive technologies provided should be increased. 
Table 1. Hierarchical regression results.

\begin{tabular}{|c|c|c|c|c|c|c|c|}
\hline $\begin{array}{l}\text { Regression/ } \\
\text { summary } \\
\text { statistics }\end{array}$ & Model 1 & Model 2 & Model 3 & Model 4 & Model 5 & Model 6 & Model 7 \\
\hline $\begin{array}{l}\text { Diagnose: } \\
\text { cancer }\end{array}$ & $\begin{array}{l}-2.159^{*} \\
(0.904)\end{array}$ & $\begin{array}{l}-1.984^{*} \\
(0.916)\end{array}$ & $\begin{array}{l}-1.949^{*} \\
(0.919)\end{array}$ & $\begin{array}{l}-1.877^{*} \\
(0.916)\end{array}$ & $\begin{array}{l}-1.709^{*} \\
(0.907)\end{array}$ & $\begin{array}{l}-1.167 \\
(0.793)\end{array}$ & $\begin{array}{l}-.191 \\
(0.675)\end{array}$ \\
\hline $\begin{array}{l}\text { Diagnose: } \\
\text { heart or car- } \\
\text { diovascular } \\
\text { disease }\end{array}$ & $\begin{array}{l}-2.035^{*} \\
(0.950)\end{array}$ & $\begin{array}{l}-1.912^{*} \\
(0.964)\end{array}$ & $\begin{array}{l}-1.920^{*} \\
(0.964)\end{array}$ & $\begin{array}{l}-1.775 \\
(0.978)\end{array}$ & $\begin{array}{l}-1.732^{*} \\
(0.964)\end{array}$ & $\begin{array}{l}-1.060 \\
(0.841)\end{array}$ & $\begin{array}{l}-.122 \\
(0.713)\end{array}$ \\
\hline $\begin{array}{l}\text { Diagnose: } \\
\text { Cerebrovas- } \\
\text { cular }\end{array}$ & $\begin{array}{l}-2.600^{* *} \\
(0.967)\end{array}$ & $\begin{array}{l}-2.404^{*} \\
(0.976)\end{array}$ & $\begin{array}{l}-2.406^{*} \\
(0.978)\end{array}$ & $\begin{array}{l}-2.369^{*} \\
(0.991)\end{array}$ & $\begin{array}{l}-2.137^{*} \\
(0.984)\end{array}$ & $\begin{array}{l}-1.140 \\
(0.869)\end{array}$ & $\begin{array}{l}-.237 \\
(0.735)\end{array}$ \\
\hline $\begin{array}{l}\text { Diagnose: } \\
\text { respiratory } \\
\text { disease }\end{array}$ & $\begin{array}{l}-.667 \\
(1.396)\end{array}$ & $\begin{array}{l}-.588 \\
(1.411)\end{array}$ & $\begin{array}{l}-.765 \\
(1.448)\end{array}$ & $\begin{array}{l}-.663 \\
(1.443)\end{array}$ & $\begin{array}{l}.265 \\
(1.506)\end{array}$ & $\begin{array}{l}.020 \\
(1.31)\end{array}$ & $\begin{array}{l}.588 \\
(1.094)\end{array}$ \\
\hline $\begin{array}{l}\text { Diagnose: } \\
\text { musculoskele- } \\
\text { tal diseases }\end{array}$ & $\begin{array}{l}-2.744^{\text {** }} \\
(0.98)\end{array}$ & $\begin{array}{l}-2.643^{* *} \\
(0.984)\end{array}$ & $\begin{array}{l}-2.544^{*} \\
(0,989)\end{array}$ & $\begin{array}{l}-2.659^{* *} \\
(0.987)\end{array}$ & $\begin{array}{l}-2.589^{* *} \\
(0.975)\end{array}$ & $\begin{array}{l}-1.179 \\
(0.863)\end{array}$ & $\begin{array}{l}-.236 \\
(0.731)\end{array}$ \\
\hline $\begin{array}{l}\text { Diagnose: } \\
\text { Alzheimer's } \\
\text { disease/ } \\
\text { dementia }\end{array}$ & $\begin{array}{l}-1.979^{*} \\
(0.962)\end{array}$ & $\begin{array}{l}-1.901 \\
(0.971)\end{array}$ & $\begin{array}{l}-1.993^{*} \\
(0.994)\end{array}$ & $\begin{array}{l}-1.957^{*} \\
(1.02)\end{array}$ & $\begin{array}{l}-1.825 \\
(1.008)\end{array}$ & $\begin{array}{l}-.895 \\
(0.872)\end{array}$ & $\begin{array}{l}-.175 \\
(0.734)\end{array}$ \\
\hline $\begin{array}{l}\text { Patient } \\
\text { residence } \\
\text { Kurzeme }\end{array}$ & & $\begin{array}{l}-.429 \\
(0.525)\end{array}$ & $\begin{array}{l}-.340 \\
(0.528)\end{array}$ & $\begin{array}{l}-.519 \\
(0.537)\end{array}$ & $\begin{array}{l}-.528 \\
(0.531)\end{array}$ & $\begin{array}{l}-.263 \\
(0.453)\end{array}$ & $\begin{array}{l}-.211 \\
(0.377)\end{array}$ \\
\hline $\begin{array}{l}\text { Patient } \\
\text { residence } \\
\text { Latgale }\end{array}$ & & $\begin{array}{l}-.961 \\
(0.550)\end{array}$ & $\begin{array}{l}-.951 \\
(0.551)\end{array}$ & $\begin{array}{l}-.979 \\
(0.569)\end{array}$ & $\begin{array}{l}-.981 \\
(0.564)\end{array}$ & $\begin{array}{l}-1.200^{*} \\
(0.511)\end{array}$ & $\begin{array}{l}-.871^{*} \\
(0.428)\end{array}$ \\
\hline $\begin{array}{l}\text { Patient } \\
\text { residence } \\
\text { Vidzeme }\end{array}$ & & $\begin{array}{l}-.157 \\
(0.363)\end{array}$ & $\begin{array}{l}-.157 \\
(0.364)\end{array}$ & $\begin{array}{l}-.175 \\
(0.367)\end{array}$ & $\begin{array}{l}-.162 \\
(0.364)\end{array}$ & $\begin{array}{l}-.127 \\
(0.311)\end{array}$ & $\begin{array}{l}-.140 \\
(0.259)\end{array}$ \\
\hline $\begin{array}{l}\text { Patient } \\
\text { residence } \\
\text { Zemgale }\end{array}$ & & $\begin{array}{l}-.196 \\
(0.503)\end{array}$ & $\begin{array}{l}-.189 \\
(0.505)\end{array}$ & $\begin{array}{l}-.215 \\
(0.504)\end{array}$ & $\begin{array}{l}.062 \\
(0.515)\end{array}$ & $\begin{array}{l}-.187 \\
(0.446)\end{array}$ & $\begin{array}{l}-.106 \\
(0.372)\end{array}$ \\
\hline $\begin{array}{l}\text { Lives with } \\
\text { relatives }\end{array}$ & & & $\begin{array}{l}-.390 \\
(0.364)\end{array}$ & $\begin{array}{l}-.278 \\
(0.37)\end{array}$ & $\begin{array}{l}-.289 \\
(0.368)\end{array}$ & $\begin{array}{l}-.454 \\
(0.315)\end{array}$ & $\begin{array}{l}-.505 \\
(0.262)\end{array}$ \\
\hline $\begin{array}{l}\text { Lives in care } \\
\text { centre }\end{array}$ & & & $\begin{array}{l}.223 \\
(0.673)\end{array}$ & $\begin{array}{l}.302 \\
(0.674) \\
\end{array}$ & $\begin{array}{l}.239 \\
(0.667)\end{array}$ & $\begin{array}{l}-.058 \\
(0.582)\end{array}$ & $\begin{array}{l}.171 \\
(0.486)\end{array}$ \\
\hline Patient's age & & & & $\begin{array}{l}-.035 \\
(0.107)\end{array}$ & $\begin{array}{l}-.060 \\
(0.110)\end{array}$ & $\begin{array}{l}-.017 \\
(0.095)\end{array}$ & $\begin{array}{l}.010 \\
(0.08)\end{array}$ \\
\hline $\begin{array}{l}\text { Patients' } \\
\text { gender }\end{array}$ & & & & $\begin{array}{l}-.501 \\
(0.297)\end{array}$ & $\begin{array}{l}-.334 \\
(0.307)\end{array}$ & $\begin{array}{l}-.277 \\
(0.265)\end{array}$ & $\begin{array}{l}-.178 \\
(0.221)\end{array}$ \\
\hline $\begin{array}{l}\text { Respondent's } \\
\text { age }\end{array}$ & & & & & $\begin{array}{l}.024 \\
(0.013)\end{array}$ & $\begin{array}{l}.013 \\
(0.011)\end{array}$ & $\begin{array}{l}.008 \\
(0.009)\end{array}$ \\
\hline $\begin{array}{l}\text { Respondent's } \\
\text { gender }\end{array}$ & & & & & $\begin{array}{l}.729 \\
(0.459)\end{array}$ & $\begin{array}{l}.647 \\
(0.39)\end{array}$ & $\begin{array}{l}.589 \\
(0.325)\end{array}$ \\
\hline $\begin{array}{l}\text { Strength of } \\
\text { the symptoms }\end{array}$ & & & & & & $\begin{array}{l}.221 \\
(0.147)\end{array}$ & $\begin{array}{l}.072 \\
(0.125)\end{array}$ \\
\hline $\begin{array}{l}\text { Assessment of } \\
\text { the needs }\end{array}$ & & & & & & $\begin{array}{l}-.162 \\
(0.133)\end{array}$ & $\begin{array}{l}-.093 \\
(0.095)\end{array}$ \\
\hline $\begin{array}{l}\text { Palliative care } \\
\text { received }\end{array}$ & & & & & & $\begin{array}{l}.710^{* * *} \\
(0.122)\end{array}$ & $\begin{array}{l}.501^{* * *} \\
(0.105)\end{array}$ \\
\hline
\end{tabular}


Table 1. Continued.

\begin{tabular}{|l|l|l|l|l|l|l|l|}
\hline $\begin{array}{l}\text { Regression/ } \\
\text { summary } \\
\text { statistics }\end{array}$ & Model 1 & Model 2 & Model 3 & Model 4 & Model 5 & Model 6 & Model 7 \\
\hline Restrictions & & & & & & $\begin{array}{l}-.077 \\
(0.134)\end{array}$ & $\begin{array}{l}.035 \\
(0.113)\end{array}$ \\
\hline Family doctor & & & & & & & $\begin{array}{l}.582^{* * *} \\
(0.083)\end{array}$ \\
\hline Intercept & $\begin{array}{l}5.667^{* * *} \\
(0.883)\end{array}$ & $\begin{array}{l}5.667^{* * *} \\
(0.885)\end{array}$ & $\begin{array}{l}5.926^{* * *} \\
(0.917)\end{array}$ & $\begin{array}{l}6.184^{* * *} \\
(1.046)\end{array}$ & $\begin{array}{l}3.596^{*} \\
(1.578)\end{array}$ & $\begin{array}{l}1.417 \\
(1.55)\end{array}$ & $\begin{array}{l}-.604 \\
(1.322)\end{array}$ \\
\hline SER & 1.53 & 1.53 & 1.53 & 1.53 & 1.50 & 1.28 & 1.06 \\
\hline Model sig & .087 & .155 & .173 & .145 & .072 & .000 & .000 \\
\hline R Square & .084 & .110 & .125 & .148 & .186 & $.435^{* * *}$ & $.612^{* * *}$ \\
\hline $\begin{array}{l}\text { R Square } \\
\text { Change }\end{array}$ & .084 & .026 & .015 & .023 & .038 & $.249^{* * *}$ & $.177^{* * *}$ \\
\hline $\begin{array}{l}\text { Adjusted } \\
\text { R Square }\end{array}$ & .040 & .036 & .036 & .046 & .072 & .332 & .537 \\
\hline F Change & 1.895 & .867 & 1.027 & 1.590 & 2.661 & 12.095 & 49.591 \\
\hline Sig. F Change & .087 & .486 & .361 & .208 & .074 & .000 & .000 \\
\hline
\end{tabular}

$* p<0.05 ; * * p<0.01 ; * * * p<0.001$.

Patient satisfaction with palliative care received

(\% split of number of responses from those who received care, scale from 1 to 4 )

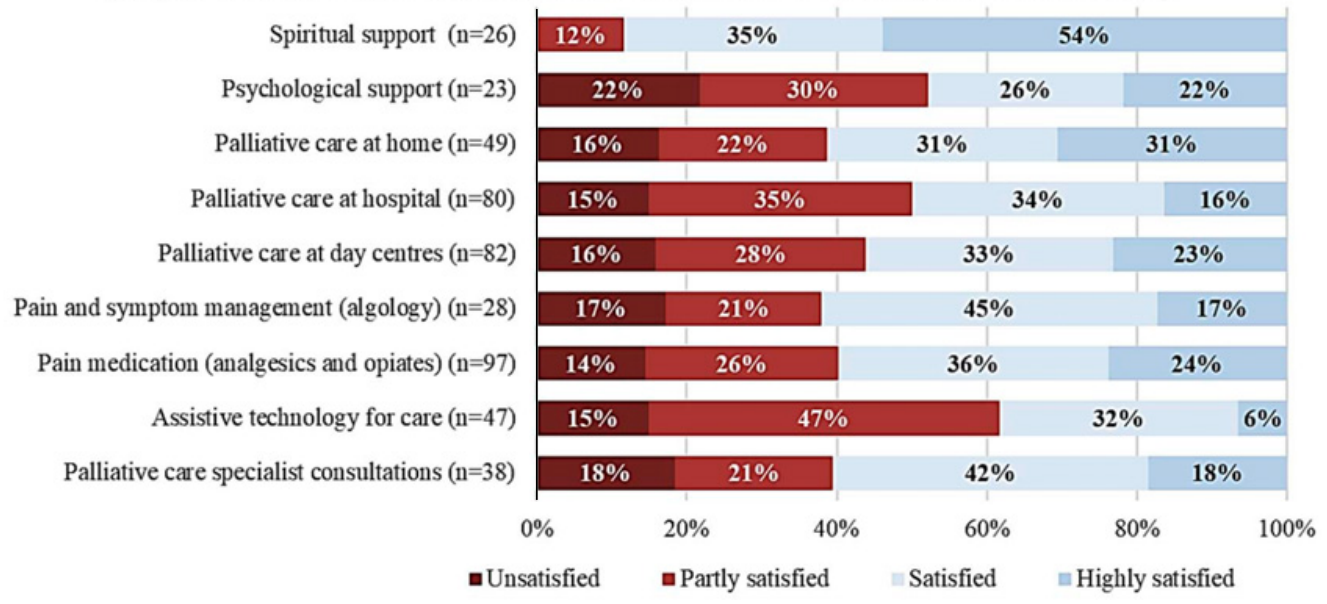

Fig. 3. Representation of patient satisfaction with care received in Latvia (2018).

The final model in Table 1 (Model 7) adds family doctor and it accounts for an additional $18 \%$ of overall satisfaction $\left(\Delta R^{2}=0.18^{* * *}\right)$. Thus, the final model explains up to $61 \%$ of overall satisfaction $\left(R^{2}=0.61\right.$ and $\left.\bar{R}^{2}=0.54\right)$. The effect of the family doctor $\left(b=0.58^{* * *}\right.$ and standardised coefficient $\beta=0.49^{* * *}$ ) appears to be even larger than that of palliative care specialist $\left(b=0.50^{* * *}\right.$ and standardised coefficient $\beta=0.37^{* * *}$ ). Thus, the results uncover the important role which family doctors have in ensuring satisfactory palliative care in Latvia.

This finding is in line with research by Ramanayake who found that family doctors have a major role to play in providing palliative care since they are closest to the community. Similarly, in US family doctors are significantly more likely to provide non-clinic-based 


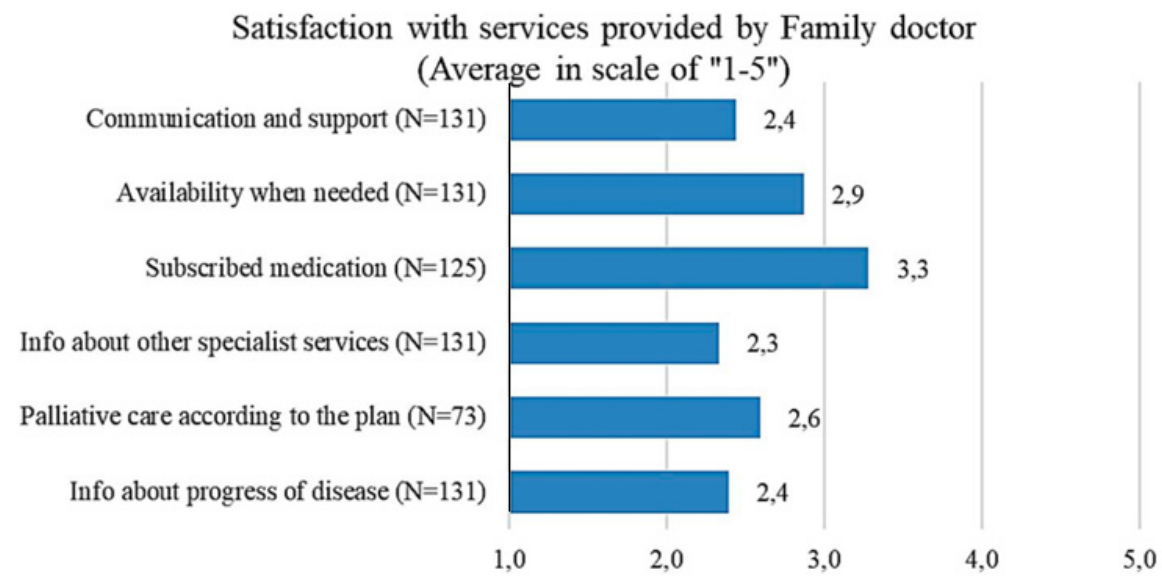

Fig. 4. Patient satisfaction with family doctor practices in Latvia (2018).

\section{Assessment of palliative care received (Average from 1-5)}

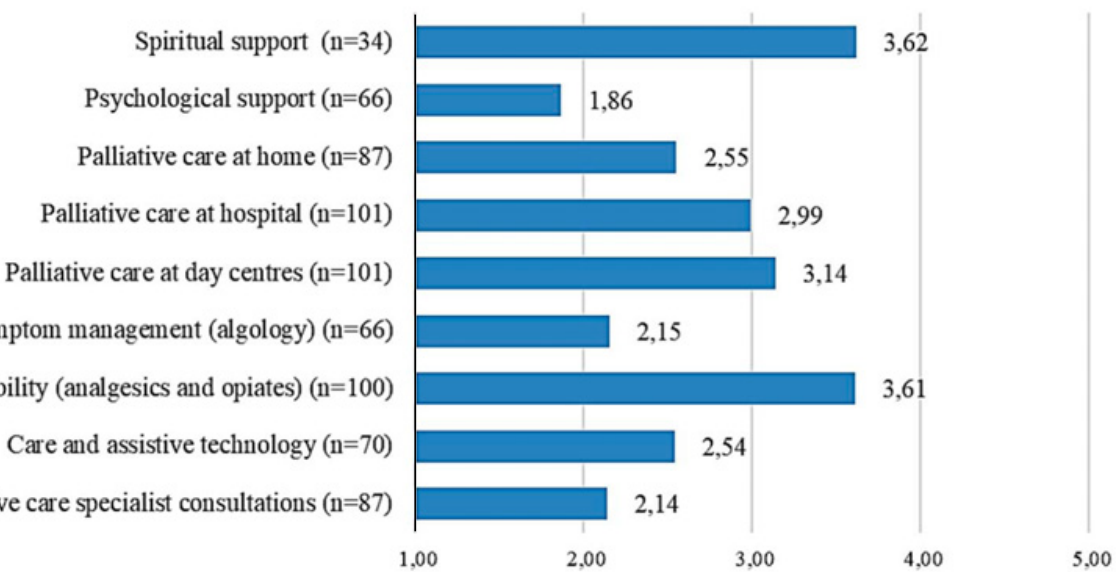

Fig. 5. Patient satisfaction with palliative care service received in Latvia (2018).

palliative care services [3]. Their role is to communicate and coordinate with other health care resources to address complex issues faced by patients [16]. Moreover, researchers have found that family doctors' tasks and roles are to ensure the integration of palliative care and collaboration [17].

The assessment of the care provided at primary level by family doctors in Latvia indicates the lack of adequate communication, insufficient information on the possibilities to receive the necessary care and services provided by other healthcare and social professionals (Fig. 4). Respondents also mentioned insufficient information delivery on the progress of the disease. Respondents also stated that care was not carried out according to a palliative care plan or it even did not exist in their opinion.

The survey also included questions about the actual availability of the service if it was needed. By accessing palliative care through special palliative services respondents mainly indicated insufficient availability of psychological support (Fig. 5 and Fig. 6), unavailability 


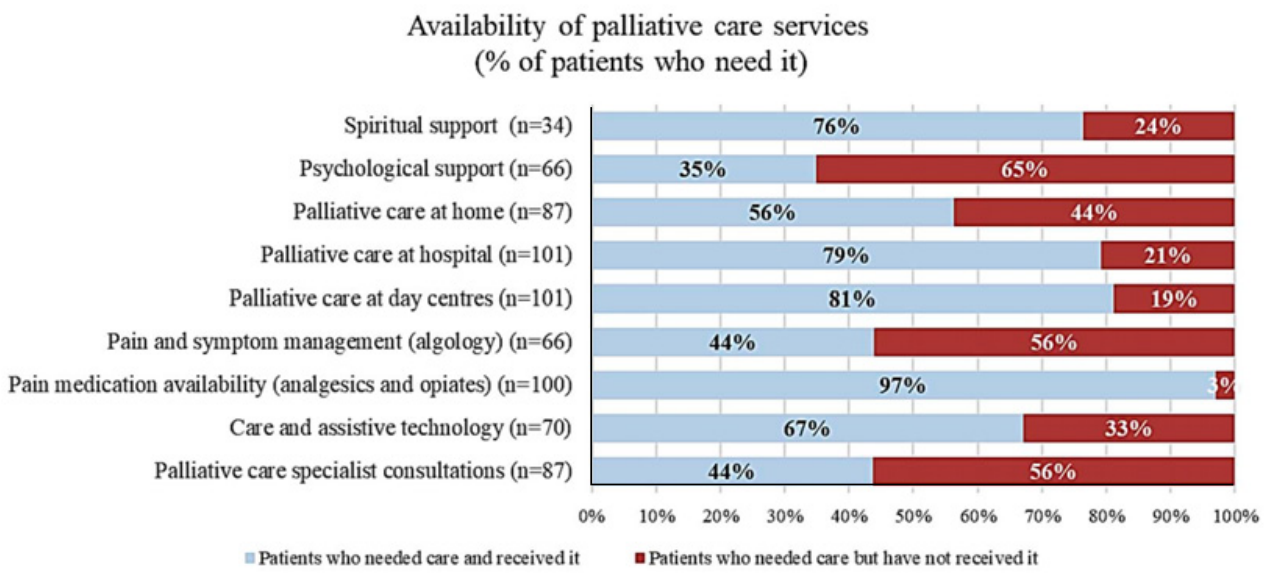

Fig. 6. Palliative care service availability in Latvia (2018).

of palliative specialist consultations and professional pain and symptom management. Other special care like spiritual support and palliative care received in day centres and hospitals were positively evaluated above the average. Highly evaluated was the availability of pain medication prescribed by family physicians.

One of the reasons of poor evaluation for special palliative care services is availability. Figure 5 shows that psychological support, palliative specialist consultations and adequate pain management is not available for more than half of the patients who desire it.

Thus, the results of the research show that particularly problematic aspect in Latvia is the psychological support. The palliative care is different from other medical fields exactly with the emphasis on the emotional support of the patient and his/her family members. It should be noted that terminal patients are particularly vulnerable to psychological disorders, existential problems, depression and suicide. The families of these patients need support to fight the loss and sadness after the family member loses the disease. This key role is exercised by different care team members, including psychologists, social workers and religious leaders (pastors, chaplains). Generally, in EU these specialists are not only responsible for the care of the patients and their families, but also for the welfare of the care team, which causes problems such as burnout [18].

Situation in Latvia shows that spiritual support is generally available and received, but the problem exists with access to psychological support.

Considering restrictions to receive palliative care, the survey data show that practically all worldwide recognised barriers regarding access to palliative care exist also in Latvia. The primary factors (Fig. 7 and Fig. 8) restricting reception of palliative care are the physical unavailability of palliative care services and too long waiting time followed by insufficient information and restricted financial coverage.

In the survey (Fig. 8) $73 \%$ of qualified respondents $(n=131)$ mentioned that there was at least one of restricting factors to receive appropriate palliative care and only $27 \%$ were not affected by any of barriers to receive appropriate palliative care. 


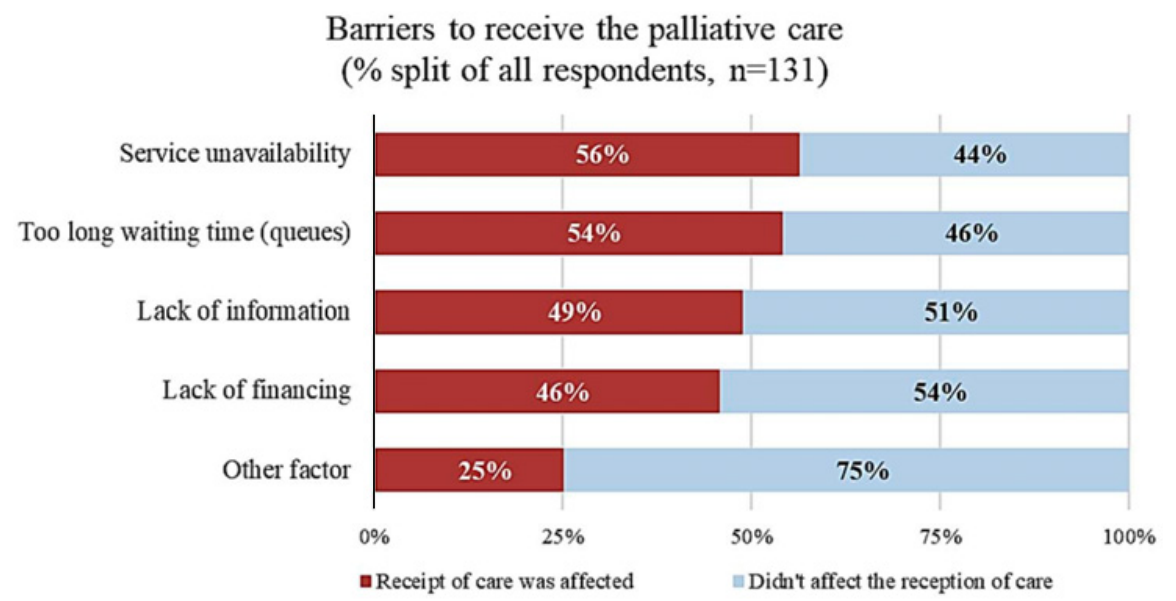

Fig. 7. Assessment of barriers to receive the palliative care in Latvia (2018).

\section{Barriers' impact on receiving the palliative care (The split in \% of all factor average impact) $(n=131)$}

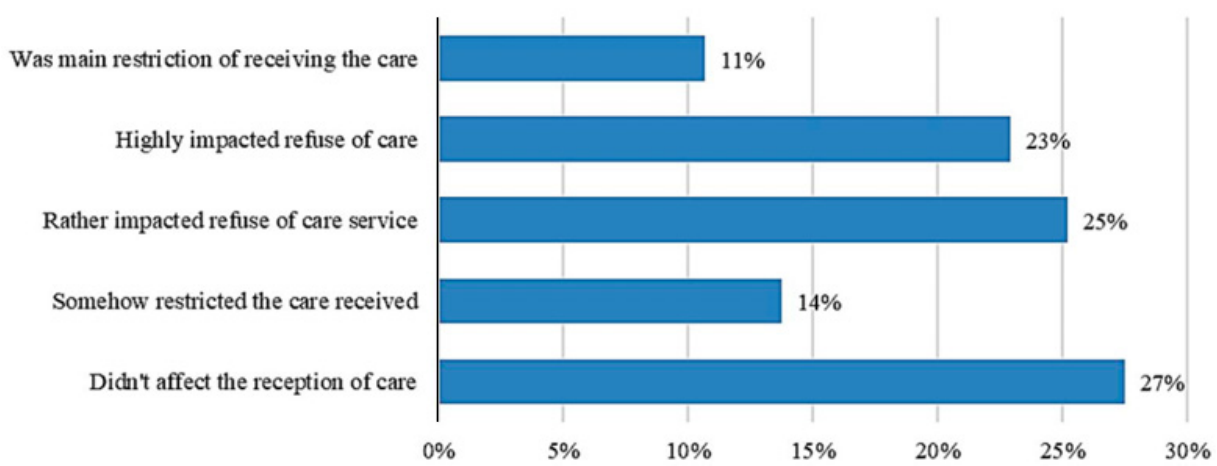

Fig. 8. Impact of barriers to receiving the palliative care in Latvia (2018).

\section{Conclusions}

The aim of this research was to evaluate the satisfaction with palliative care and its availability in Latvia, as well as identify factors which have a major impact on overall satisfaction with care.

According to the first research question (which factors contribute to satisfaction of palliative care in Latvia and what the role of the family doctor is), the survey analysis highlighted the crucial role of family doctors as the most important factor contributing to overall satisfaction with the care, and service provided by palliative care specialists being the second important factor. Results also show that the communication and exchange of information between those specialists and information provided to patients and their family members are crucial to ensure the patient needs and to improve the palliative care. Indeed, as stated by Ramanayake, developing palliative care models should include opportunities for family doctors to learn sound palliative care principles in order to meet the challenges of the future [16]. 
In Latvia, there is a need to establish an interdisciplinary team approach not only between the healthcare specialists but also social care specialists that should be involved in ensuring qualitative palliative care. According to the concept developed by Sisli Sounders, modern palliative care includes a holistic model of care provided by a multidisciplinary team. Moreover, modern palliative care is centred on general health care for patient care according to his needs. The patient and his/her relatives are not only recipients of care, but also active team members [19].

According to the second research question (what the restrictions to the availability of palliative care in Latvia are), the survey results provide an idea of the necessary improvements in palliative care in Latvia. There is a need to increase the availability of palliative care services across all regions of Latvia and to inform the population about the palliative care and how to access it. The situation in Latvia shows that while spiritual support is generally available and received when needed the problem exists with availability and access to psychological support. Consequently, there is also a need to increase the funding to finance the whole spectrum of palliative care services thus increasing access to them.

Palliative care should be available from the time of diagnosis to anyone who is experiencing a serious, chronic illness or other life-threatening or terminal illness. Such patients and their family members in addition to curative therapy need support and care provided by primary and secondary healthcare professionals, social workers, psychologists, and chaplain.

The study indicated that there is no unified and comprehensive palliative care strategy and system in Latvia, however, some publicly funded care is available for a limited amount of oncology patients. The world literature and models available may serve as a basis for Latvia policymakers to develop unified and comprehensive end-of-life or palliative care strategy in Latvia.

\section{References}

[1] World Health Organization, Global Atlas of Palliative Care at the End of Life (2014). Online: http://www.who.int/nmh/Global_Atlas_of_Palliative_Care.pdf

[2] World Health Organization, Palliative care (2018). Online: https://www. who.int/en/news-room/fact-sheets/detail/palliative-care

[3] OECD, Health at a Glance 2017: OECD Indicators, OECD Publishing, Paris (2017). Online: http://dx.doi.org/10.1787/health_glance-2017-en

[4] C.K. Ankuda, A. Jetty, A. Bazemore S. Petterson, J. Am. Board Fam. Med. 30, 255 (2017)

[5] World Health Organization, Planning and Implementing Palliative Care Services: A Guide for Programme Managers, World Health Organization, Geneva (2016). Online: http://www . who.int/iris/handle/10665/250584

[6] National Institute of Aging, What Are Palliative Care and Hospice Care? (2018). Online: https://www.nia.nih.gov/health/what-are-palliativecare-and-hospice-care

[7] M. Pardo, R.D. Miller, Palliative Care in Basics of Anesthesia, edited by S. Gebauer, 7 ed. (Philadelphia, PA, Elsevier, Inc., 2017), p. 829

[8] S.B.E. Yennurajalingam, Oxford American Handbook of Hospice and Palliative Medicine (Oxford: Oxford University Press, 2011)

[9] M.A.A.P.A.M. Timothy, E. Quill, N. Engl. J. Med. 368(13), 1173-5 (2013)

[10] P. Hawley, Barriers to Access to Palliative Care, Palliat Care 10, 1-6 (2017)

[11] World Health Assembly, Resolution WHA67.19, Geneva: World Health Organization (2014) 
[12] X. Gómez-Batiste, M. Martínez-Muñoz, C. Blay, J. Amblàs, L. Vila, X. Costa, J. Espaulella, J. Espinosa, C. Constante, G.K. Mitchell, Palliat Med. 28, 302 (2014)

[13] P.M. Podsakoff, S.B. MacKenzie, N.P. Podsakoff, Annu. Rev. Psychol. 63, 539 (2012)

[14] G. Darren, P. Mallery, SPSS for windows Step by Step (Pearson Education, 2003)

[15] A. Field, Discovering Statistics using IBM SPSS Statistics 5 ed., SAGE (2018)

[16] R. Ramanayake, G. Dilanka, L. Premasiri, J. Family Med. Prim. Care 5, 234 (2016)

[17] K. Beernaert, L. Van der Block, K. Van Thienen, D. Devroey, K. Pardon, L. Delien, J. Cohen, Fam Pract. 6, 694 (2015)

[18] J.M. Martin-Moreno, M. Harris, L. Gorgojo, D. Clark, C. Normand, C. Centeno, Policy Department Economic and Scientific Policy, Palliative Care in the European Union, European Parliament, (2008). Online: http: //www. europarl .europa.eu/ RegData/etudes/etudes/join/2008/404899/IPOL-ENVI_ET\%282008\%294048 99_EN.pdf

[19] Laže, O. Gusakova, E. Bladiko, I. Mockus, G. Āmara, ESF, Onkologiskās aprūpes Māsas papildspecialitāte, Rīga, Nacionālais apgāds (2009) 